\title{
Pancytopenia due to iron deficiency worsened by iron infusion: a
} \section{case report}

\author{
Apar Kishor Ganti*1,2, Nicole A Shonka ${ }^{3}$ and William D Haire ${ }^{1}$
}

Address: ${ }^{1}$ Department of Internal Medicine, Division of Oncology/Hematology, University of Nebraska Medical Center, Omaha, NE, USA, ${ }^{2}$ VA Medical Center, Omaha, NE, USA and ${ }^{3}$ Department of Internal Medicine, University of Nebraska Medical Center, Omaha, NE, USA

Email: Apar Kishor Ganti* - aganti@unmc.edu; Nicole A Shonka - nshonka@unmc.edu; William D Haire - whaire@unmc.edu

* Corresponding author

Published: 7 December 2007

Journal of Medical Case Reports 2007, I:175 doi:10.1 I86/1752-1947-I-175

Received: 3 July 2007

Accepted: 7 December 2007

This article is available from: http://www.jmedicalcasereports.com/content/I/I/175

(c) 2007 Ganti et al; licensee BioMed Central Ltd.

This is an Open Access article distributed under the terms of the Creative Commons Attribution License (http://creativecommons.org/licenses/by/2.0), which permits unrestricted use, distribution, and reproduction in any medium, provided the original work is properly cited.

\begin{abstract}
Introduction: Iron deficiency anemia is commonly associated with thrombocytosis, although thrombocytopenia has been reported in occasional patients with iron-deficiency anemia. Much less common is the development of thrombocytopenia following replenishment of iron stores.

Case Presentation: We present the unusual case of a 39 year old African American female Jehovah's Witness who presented with a 10 month history of menorrhagia and pancytopenia. Laboratory investigations confirmed a severe iron deficiency. Since blood transfusion was unacceptable to her, she was started on intravenous iron replacement therapy. This precipitated a sudden drop in both her platelet and white blood cell counts. Histopathological examination of the bone marrow revealed a hypercellular marrow with orderly trilineage hematopoiesis, iron deficiency anemia, granulocytic hyperplasia, and mild megakaryocytic hypoplasia. Both her white blood cell and platelet counts recovered uneventfully with continuing iron supplementation. The possible mechanism for this phenomenon is discussed in this report.

Conclusion: This case illustrates two rather uncommon associations of a very common problem. Severe iron deficiency anemia may be associated with pancytopenia and iron replacement may cause a transient decline in megakaryopoiesis and leukopoiesis. Severe iron deficiency should be added to the list of conditions leading to thrombocytopenia.
\end{abstract}

\section{Introduction}

Iron deficiency anemia is the second most common nutritional deficiency in the United States [1] with an estimated 3.3 million women of child bearing age suffering from the condition [2].

Iron deficiency anemia is commonly associated with thrombocytosis with platelet counts between 500 to 700 $\times 10^{9} / \mathrm{L}$ [3]. The mechanism for this increase in platelet counts is thought to be the stimulation of platelet production by erythropoietin that is present in moderately increased levels in patients with iron-deficiency anemia [4]. Thrombocytopenia, although relatively uncommon in the setting of iron-deficiency anemia, has been reported before [5-7]. Another little known phenomenon is the development of thrombocytopenia following replenishment of iron stores $[8,9]$. A mild leukopenia has been reported with iron-deficiency anemia as well [10]. However, a decline in leukocyte counts following iron therapy has not been reported for leukocytes. 
In this report, we present the unusual case of a severely iron deficient patient who presented initially with pancytopenia and then developed a precipitous decline followed by a recovery in platelet and leukocyte counts after iron replacement.

\section{Case presentation}

A 39 year old African American female Jehovah's Witness with a ten-month history of menorrhagia was admitted for severe anemia and pancytopenia. Her hemoglobin on admission (Hgb) was $3.1 \mathrm{~g} / \mathrm{dL}$ (normal range: 11.0 - 15.1 $\mathrm{gm} / \mathrm{dL}$ ), mean corpuscular volume was $58.6 \mathrm{fL}$ (normal range: $79-97 \mathrm{fL}$ ) and red cell distribution width (RDW) was 35\% (normal range: 11.3 - 15.5\%). Reticulocyte count was low at $8000 / \mathrm{mm}^{3}$ (normal range: $25-100 \times$ $10^{3} / \mathrm{mm}^{3}$ ), and iron studies revealed a serum iron level of $17 \mu \mathrm{g} / \mathrm{dL}$ (normal range: $37-170 \mu \mathrm{g} / \mathrm{dL}$ ), total iron binding capacity of $447 \mu \mathrm{g} / \mathrm{dL}$ (normal range: $250-450 \mu \mathrm{g} /$ $\mathrm{dL}$ ), percentage saturation of 4 and a ferritin level of $<2$ $\mathrm{ng} / \mathrm{mL}$ (normal range: $10-100 \mathrm{ng} / \mathrm{mL}$ ). Erythropoietin level was elevated at $9544 \mathrm{mU} / \mathrm{mL}$ (normal range: $0-27$ $\mathrm{mU} / \mathrm{mL}$ ). White blood cell (WBC) count was $2.9 \times 10^{3} / \mu \mathrm{L}$ (normal range: $4-11 \times 10^{3} / \mu \mathrm{L}$ ) with 46 segmented neutrophils, and her platelet count was $127 \times 10^{3} / \mathrm{mcL}$ (normal range: $\left.150-400 \times 10^{3} / \mu \mathrm{L}\right)$, and coagulation parameters were normal.

Given her faith, transfusion was unacceptable, and iron supplementation was begun with intravenous iron sucrose complex given at a dose of $100 \mathrm{mg}$ twice weekly. Two days after the initial iron infusion, her pancytopenia worsened with a drop in her platelets to $39 \times 10^{3} / \mathrm{mcL}$, hemoglobin decreased marginally to $2.7 \mathrm{gm} / \mathrm{dL}$, and WBC count decreased to $1.6 \times 10^{3} / \mathrm{mcL}$. Given this sudden drop in hemoglobin, white blood cell counts and platelet counts, a bone marrow biopsy was performed to exclude a primary marrow disorder. Histopathological examination of the marrow revealed a hypercellular marrow, normal number of erythroid cells with a focus of left-shifted erythropoiesis, mildly decreased number of megakaryocytes. Evaluation of iron stores in the bone marrow showed decreased amounts of storage iron, but there was incorporation of iron. Ringed sideroblasts were not present in the bone marrow core sections.

After ten days of iron therapy, her WBC count had normalized to $5.9 \times 10^{3} / \mathrm{mcL}$, hemoglobin improved to $5.2 \mathrm{~g} /$ $\mathrm{dL}$, and platelets were $195 \times 10^{3} / \mathrm{mcL}$. She received a total of $1500 \mathrm{mg}$ of intravenous iron and at four months following completion of therapy, her hemoglobin (14.0 gm/ $\mathrm{dL})$, platelet counts $\left(181 \times 10^{3} / \mathrm{mcL}\right)$ and ferritin level $(121 \mathrm{ng} / \mathrm{mL})$ were within normal limits. Her WBC count was $3.8 \times 10^{3} / \mathrm{mcL}$, slightly below the lower limits of normal (Figure 1).
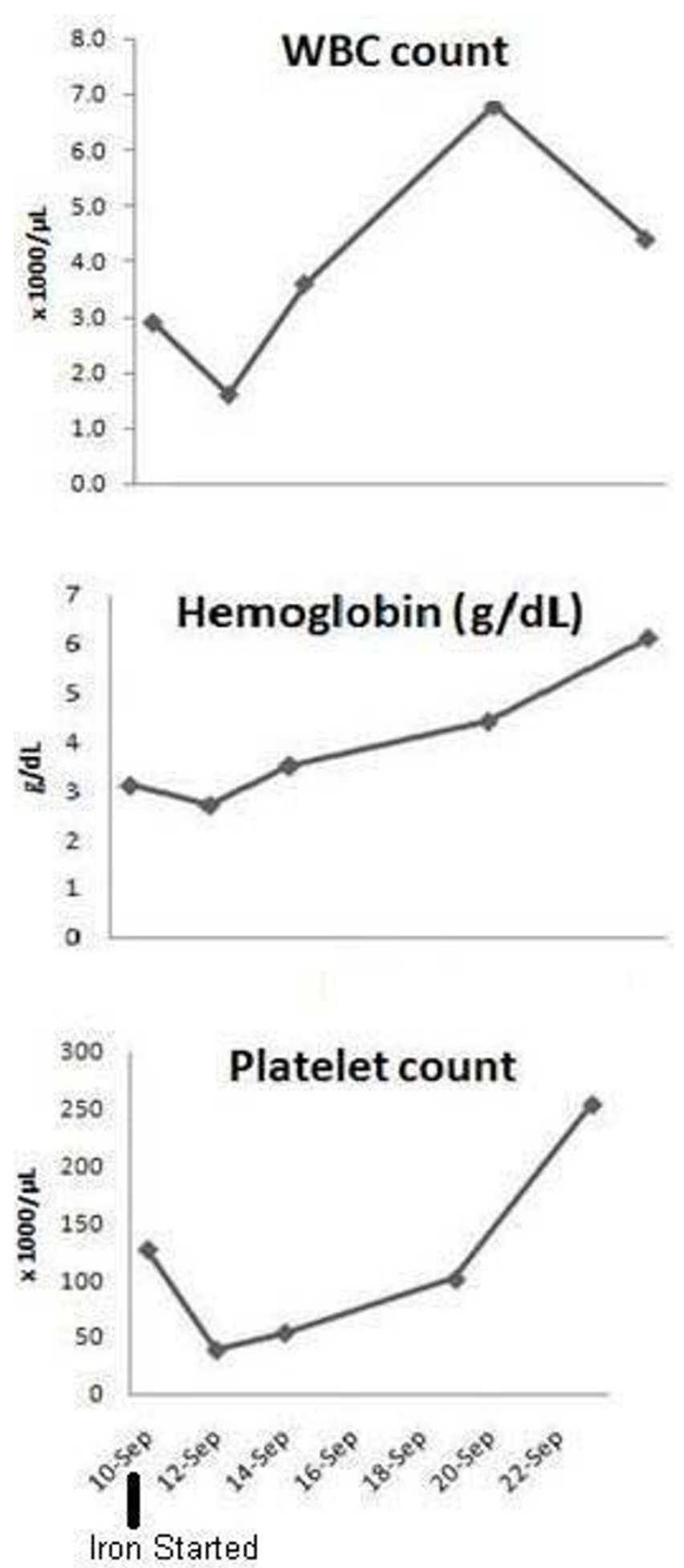

Figure I

Temporal profile of hemoglobin, white blood cell and platelet counts. 


\section{Discussion}

Our patient presented with pancytopenia. Given the extreme anemia and the marginal thrombocytopenia and leukopenia, she was initiated on iron replacement therapy in order to improve erythropoiesis. This led to a sudden decline in platelet and WBC counts (Figure 1).

Although iron deficiency is associated with a reactive thrombocytosis [3], increasing severity of the iron deficiency leads to normalization $[11,12]$ and occasionally even decrease in platelet counts [5-7]. The exact mechanism of this is unclear but may be related to the alteration in the activity of iron dependent enzymes in thromboand leukopoiesis.

The mechanism of leukopenia in our patient may be related to the extremely high levels of erythropoietin seen in our patient. Animal experiments and in vitro studies using human hematopoietic stem cells have demonstrated that addition of erythropoietin to these stem cells down-regulates neutrophil production [13].

The sudden transient decrease in the platelet and leukocyte counts following iron therapy is probably related to the phenomenon of stem cell steal. Increased availability of the deficient erythrocyte precursor (iron) may have led to the diversion of the pluripotent hematopoietic stem cells towards erythropoiesis, at the expense of the other hematopoietic cell lines. In fact, the effect of erythropoietin therapy on platelet counts has been shown to be dependant on the adequacy of iron stores. When iron supply is inadequate, intense erythropoietin stimulation may cause thrombocytosis, but when iron supply is available, erythropoiesis predominates and megakaryopoiesis may be transiently decreased [14].

\section{Conclusion}

This case illustrates two relatively uncommon findings in an extremely common disease. Iron deficiency anemia, if sufficiently severe, may be associated with decreased platelet and WBC counts and iron replacement therapy may cause a transient decline in megakaryopoiesis and leukopoiesis.

\section{Competing interests}

The author(s) declare that they have no competing interests.

\section{Authors' contributions}

AKG conceived the study, contributed to acquisition of data and drafted the initial manuscript and revised the manuscript prior to submission. NAS helped with the acquisition of the data, designing and drafting the initial draft, and revised the draft. WDH was the clinician responsible for making the treatment decisions on the patient. He also made contributions to acquisition of data, and revised the draft as necessary. All authors have read and approved the final manuscript.

\section{Consent}

The patient was informed about the intent to publish this report and consented to the same in writing.

\section{Acknowledgements}

There is no source of funding for this manuscript

\section{References}

I. Fairbanks VF, Beutler E: Iron deficiency. In Williams Hematology 6th edition. Edited by: Beutler E, Lichtman MA, Coller BS, Kipps TJ, Seligsohn U. New York: McGraw-Hill; 200 I:447-470.

2. Looker AC, Dallman PR, Carroll MD, Gunter EW, Johnson CL: Prevalence of iron deficiency in the United States. JAMA 1997, 277:973-976.

3. Schloesser LL, Kipp MA, Wenzel FJ: Thrombocytosis in iron deficiency anemia. J Lab Clin Med 1965, 66:107-I I4.

4. Beguin Y: Erythropoietin and platelet production. Haematologica 1999, 84:54I-547.

5. Lopas H, Rabiner SF: Thrombocytopenia associated with iron deficiency anemia. Clin Pediatr 1966, 5:609-616.

6. Berger M, Brass LF: Severe thrombocytopenia in iron deficiency anemia. Am J Hematol 1987, 24:425-428.

7. Mubarak AA, Awidi A, Rasul KI, Al-Homsi U: Thrombocytopenia responding to red blood cell transfusion. Saudi Med J 2004, 25:106-109.

8. Soff GA, Levin J: Thrombocytopenia associated with repletion of iron in iron-deficiency anemia. Am J Med Sci 1988, 295:35-39.

9. Go RS, Porrata LF, Call TG: Thrombocytopenia after iron dextran administration in a patient with severe iron deficiency anemia. Ann Intern Med 2000, 132:925.

10. Tichelli A, Gratwohl A, Speck B: Iron-deficiency anemia: diagnosis and therapy. Schweiz Med Wochenschr 1992, 122:46I-465.

II. Dincol K, Aksoy M: On the platelet levels in chronic iron deficiency anemia. Acta Haematol 1969, 41: |35-143.

12. Choi SI, Simone JV, Jackson CW: Megakaryocytopoiesis in experimental iron deficiency anemia. Blood 1974, 43: I I I- I20.

13. Christensen RD, Liechty KW, Koenig JM, Schibler KR, Ohls RK: Administration of erythropoietin to newborn rats results in diminished neutrophil production. Blood |99|, 78: |24|-| 246.

14. Loo M, Beguin Y: The effect of recombinant human erythropoietin on platelet counts is strongly modulated by the adequacy of iron supply. Blood 1999, 93:3286-3293.

Publish with Bio Med Central and every scientist can read your work free of charge

"BioMed Central will be the most significant development for disseminating the results of biomedical research in our lifetime. " Sir Paul Nurse, Cancer Research UK

Your research papers will be:

- available free of charge to the entire biomedical community

- peer reviewed and published immediately upon acceptance

- cited in PubMed and archived on PubMed Central

- yours - you keep the copyright 